\title{
Vitamin D level and its association with adiposity among multi-ethnic adults in Kuala Lumpur, Malaysia: a cross sectional study
}

\author{
I. S. Shafinaz and F. M. Moy*
}

\begin{abstract}
Background: Vitamin D deficiency is highly prevalent in both temperate as well as tropical countries. Obesity is one of the factors contributing to vitamin D deficiency. As our country has a high prevalence of overweight and obesity, we aimed to study serum 25-hydroxyvitamin D $(25(\mathrm{OH}) \mathrm{D})$ level and its association with adiposity using various adiposity indicators; and to study other risk factors that affect serum 25(OH)D level among multi-ethnic adults in Kuala Lumpur, Malaysia.
\end{abstract}

Methods: This was a cross sectional study conducted with a multistage sampling. All permanent teachers working in government secondary schools in Kuala Lumpur were invited for the study. The data collection included serum 25(OH)D, Parathyroid Hormone (PTH), body fat percentage, waist circumference, body mass index (BMI) and blood pressure. Demographic characteristics, sun avoidance, sun exposure and physical activity were enquired from the participants using a self-administered questionnaire. The data was analyzed using a complex sample analysis.

Results: A total of 858 participants were recruited. Majority of them were Malays, females and had tertiary education. The overall prevalence of vitamin D deficiency $(<20 \mathrm{ng} / \mathrm{ml})$ was $67.4 \%$. Indian participants $(80.9 \%)$ had the highest proportion of vitamin D deficiency, followed by Malays (75.6\%), others (44.9\%) and Chinese (25.1\%). There was a significant negative association between serum $25(\mathrm{OH}) \mathrm{D}$ level with BMI $(\beta=-0.23)$ and body fat percentage $(\beta=-0.14)$. In the multivariate linear regression analysis, Malays, Indians and females $(p<0.001)$; higher $\mathrm{BMI}$ and larger waist circumference $(p<0.05)$ were significantly associated with lower serum $25(\mathrm{OH}) \mathrm{D}$ level. The full model explained $32.8 \%$ of the variation between participants in the serum 25(OH)D level. The two most influential factors affecting serum 25(OH)D level were ethnicity and gender.

Conclusions: The prevalence of vitamin D deficiency among our participants was high. Adiposity was associated with serum 25(OH)D level. Skin pigmentation and gender based behaviours were more dominant in contributing to serum 25(OH)D level. Health education should be targeted in weight management, gender based behaviours on sun exposure, as skin pigmentation is non-modifiable.

Keywords: 25(OH)D, BMI, Body fat percentage, Waist circumference, Physical activity, Sun avoidance

\footnotetext{
* Correspondence: moyfm@ummc.edu.my

Julius Centre University of Malaya, Department of Social \& Preventive

Medicine, Faculty of Medicine, University of Malaya, 50603 Kuala Lumpur,

Malaysia
} 


\section{Background}

Vitamin D plays an essential role in health. Its deficiency increases the risk of osteoporosis as well as contributes to cardiovascular diseases, diabetes and cancers [1-3]. Skin synthesis of vitamin D from sunlight exposure is the major source of vitamin D [4]. Evidences show that temperate countries, as well as tropical countries like Malaysia, Thailand, Saudi Arabia and Iran [5-8] experience the problem of vitamin D deficiency.

Vitamin D status can be measured using 1,25-dihydroxyvitamin $\mathrm{D}\left(1,25(\mathrm{OH})_{2} \mathrm{D}\right)$ and 25-hydroxyvitamin $\mathrm{D}$ $(25(\mathrm{OH}) \mathrm{D})$. However, the circulating $25(\mathrm{OH}) \mathrm{D}$ is considered a better marker to determine vitamin $\mathrm{D}$ status as it has a long circulating half-life of 14 to 20 days [9]. In contrast to $25(\mathrm{OH}) \mathrm{D}, 1,25(\mathrm{OH})_{2} \mathrm{D}$ is less used to determine vitamin D status due to its short half-life (approximately 15 hours). Its serum concentration is also closely regulated by parathyroid hormone (PTH), phosphate and calcium [10]. In addition, $1,25(\mathrm{OH})_{2} \mathrm{D}$ level does not typically decrease until there is a severe vitamin $\mathrm{D}$ deficiency $[11,12]$.

Malaysia is an upper middle income country and its prevalence of obesity is high. According to the National Health Morbidity Survey in 2011, the prevalence of overweight and obesity among adults aged 18 years and above was $29.4 \%$ and $15.4 \%$ respectively [13]. One of the factors contributing to vitamin $\mathrm{D}$ deficiency is obesity. Obesityassociated vitamin $\mathrm{D}$ deficiency is most likely due to the decreased bioavailability of vitamin $\mathrm{D}$ with the deposition of vitamin D in the adipose tissue [14]. It is also hypothesized that a reduced circulating vitamin $\mathrm{D}$ in the form of calcidiol stimulates an accumulation of fat mass, giving rise to obesity and the induction of metabolic syndrome. It may be possible to reverse the condition of obesity by improving vitamin D status [15]. Based on this evidence, it is expected that obese individuals may need higher than the usual doses of vitamin D. However, it remains unclear of which indicator of adiposity, i.e., body mass index, waist circumference or percentage of body fat that should be taken into consideration while assessing vitamin D status in the general population.

Body Mass Index (BMI) is commonly used to determine one's healthy weight with reference to the individual's height. Many studies used BMI to measure obesity $[5,16]$ as it is simple, effective and quick to be applied on adults and children. Waist circumference is used to estimate visceral fat or central obesity. However, both of these indicators are indirect measures of body fat. Body fat percentage, which is a direct measure of total body fat, can be measured by the Dual Energy X-ray Absorptiometry (DEXA) or the Bioelectrical Impedance Analyzer (BIA).

There is a scarcity of published reports on the association of adiposity and vitamin D status among the adult population in Malaysia. To date, the only available
Malaysian studies on vitamin D amongst adults are the vitamin $\mathrm{D}$ status among postmenopausal Malaysian women [16]; the status of vitamin D among women with child bearing-age [17]; the vitamin D status on obesity, metabolic syndrome and cardio-metabolic risks among females in Kuala Lumpur [18]; the effects of nutrition education and sun exposure on vitamin D status among postmenopausal Malay women which was extended from Rahman's study [19]; the effects of sun exposure on $25(\mathrm{OH}) \mathrm{D}$ concentration among urban and rural women in Kuala Lumpur and Negeri Sembilan [20] and the latest study reported the vitamin D status among Malaysian men and its associated factors [21]. Among these, two studies used the BIA to relate body fat percentage with vitamin D status $[20,21]$. However, that association was not the researchers' main focus [20] and the study by Chin et al. was only limited to men [21], while the rest of the studies used BMI, an indirect measurement of adiposity.

Therefore, we aimed to study the association of serum $25(\mathrm{OH}) \mathrm{D}$ level and adiposity using various adiposity indicators and to study other risk factors that affect serum $25(\mathrm{OH}) \mathrm{D}$ level among multi-ethnic adults in Kuala Lumpur.

\section{Methods}

\section{Study design}

This was a cross sectional study, conducted from February to May 2013 and it was part of the CLUSTer cohort study [22].

\section{Study population}

All permanent teachers who worked in the selected government secondary schools in Kuala Lumpur were invited to participate. Teachers were selected because they are easily accessible during working hours and they are one of the largest group of workers in the country.

\section{Sampling method}

A two stage sampling method was carried out. First, $50 \%$ of all government secondary schools $(n=87)$ from all districts (Pudu, Bangsar, Sentul, Keramat) in Kuala Lumpur were randomly selected. Then, all teachers from the selected schools, except those who were pregnant, were invited to participate in the study. Pregnant teachers were excluded as their levels of adiposity and requirement for vitamin $\mathrm{D}$ may be different from those who were not pregnant.

\section{Ethics clearance, approval and informed consent}

Ethics clearance was obtained from the University Malaya Medical Centre (UMMC) Ethics Committee (Reference Number: 950.1) that governs all studies on human within the Medical Faculty. Approval from the Ministry 
of Education, Malaysia; the Education Board of Wilayah Persekutuan Kuala Lumpur and the principals from each selected schools were obtained before data collection. Informed consent was obtained from all participants.

\section{Data collection}

The data collected included 1) serum 25(OH)D and $\mathrm{PTH}, 2)$ fat percentage using the Bioelectrical Impedance Analyzer (BIA), 3) anthropometric measurements (BMI and waist circumference) and 4) blood pressure. A fasting venous blood sample was collected for serum 25(OH)D and PTH analysis. The blood samples were spun at 3000 revolutions per minute (RPM) for $15 \mathrm{mi}$ nutes. Then, the serum was separated and stored in a $-80{ }^{\circ} \mathrm{C}$ freezer until the analyses of vitamin D and PTH were carried out. Electro-chemiluminescence immunoassay (ECLIA) on the Cobas E-411 analyzer was used to analyse serum $25(\mathrm{OH}) \mathrm{D}$. The inter-assay coefficient of variation $(\mathrm{CV})$ was $3.6 \%$ at $22.8 \mathrm{ng} / \mathrm{ml}$ and $3.0 \%$ at $68.2 \mathrm{ng} / \mathrm{ml}$, while the intra-assay $\mathrm{CV}$ was $3.5 \%$ at $22.8 \mathrm{ng} / \mathrm{ml}$ and $2.9 \%$ at $68.2 \mathrm{ng} / \mathrm{ml}$. The measuring range for this kit was 4 to $100 \mathrm{ng} / \mathrm{ml}$. Serum PTH was analyzed using the ECLIA PTH on the Cobas E-411 analyzer. The inter-assay coefficient of variation $(\mathrm{CV})$ was $6.2 \%$ at $2.14 \mathrm{pmol} / \mathrm{L}$ and $4.1 \%$ at $6.15 \mathrm{pmol} / \mathrm{L}$, while the intra-assay $\mathrm{CV}$ was $4.1 \%$ at $2.14 \mathrm{pmol} / \mathrm{L}$ and $2.2 \%$ at $6.15 \mathrm{pmol} / \mathrm{L}$. The measuring range of this kit was 0.127 to $530 \mathrm{pmol} / \mathrm{L}$.

Serum 25(OH)D less than $20 \mathrm{ng} / \mathrm{ml}$ or $50 \mathrm{nmol} / \mathrm{l}$ was considered as vitamin D deficient, according to the US Endocrine Society Clinical Practice Guidelines [23]. PTH was measured along with $25(\mathrm{OH}) \mathrm{D}$ as both are responsible for maintaining extracellular calcium homeostasis [24] and to rule out vitamin $\mathrm{D}$ deficiency due to hyperthyroidism.

Height was measured using a stadiometer (Seca, Germany). Body fat percentage and weight were measured using the foot-to-foot Bioelectrical Impedance Analyzer (Tanita TBF-300A) and a weighing scale (Seca, Germany) respectively, with socks and shoes removed. Body mass index (BMI) was calculated as weight in kilograms divided by the square of height in meters. Following the recommendations of World Health Organization for Asians [25], a BMI of less than $17.5 \mathrm{~kg} / \mathrm{m}^{2}$ was categorised as underweight and $\mathrm{BMI}$ in the range of 17.5 to $22.9 \mathrm{~kg} / \mathrm{m}^{2}$ was healthy/normal. BMI of 23.0 to $27.9 \mathrm{~kg} /$ $\mathrm{m}^{2}$ was considered as overweight, whereas BMI above or equal $28.0 \mathrm{~kg} / \mathrm{m}^{2}$ was categorised as obese. The waist was measured at the midpoint between the lower costal margin (lower rib) and the iliac crest (top of the pelvic bone) $[25,26]$. Waist circumference of more and equal to $90 \mathrm{~cm}$ and $80 \mathrm{~cm}$ for men and women respectively was considered at risk or abnormal. Blood pressure was measured using the clinical validated digital automatic blood pressure machine (OMRON HEM Model- 907) while the participants were in a seated position.

Socio-demographic characteristics such as age, gender, ethnicity, religion and marital status were enquired. A validated questionnaire on sun exposure and avoidance practices was administered. Participants were asked about their outdoor activities and clothing styles like wearing long sleeves, long skirts, hat/cap, veils, and use of umbrellas and sun block lotions. Sun avoidance score was derived through the sum of all types of avoidance as mentioned above $(\max =8, \min =0)$, while sun exposure score was derived by multiplying the duration in minutes of sun exposure per day with the number of days per week [18]. Physical activity was assessed using the validated Malay International Physical Activity Questionnaire (IPAQ-M) short form [27]. All continuous scores were expressed in MET-minutes/week. For the calculation of IPAQ-M data, the following MET-values were used: walking $=3.3 \mathrm{METs}$, moderate physical activity = 4.0 METs and vigorous physical activity $=8.0$ METs. The MET-minutes per week (MET-min week ${ }^{-1}$ ) was calculated as minutes of activity/day $\mathrm{x}$ days per week $\mathrm{x}$ MET level. Finally, total physical activity MET-minutes/ week was calculated as the sum of walking + moderate + vigorous MET-minutes/week scores.

\section{Data analysis}

Statistical analysis was performed using the Statistical Package for Social Sciences for Windows, version 22.0 (SPSS Inc., Chicago, IL, USA). Weighted means \pm standard deviation (SD) and proportions were calculated for descriptive data. Complex Sample Analysis was used. Final weightage was calculated by multiplying schools' weightage and teachers' weightage. Weightage was used in the Complex Sample Analysis to correct the unequal probabilities of non-respondence.

Independent t-test, analysis of variance (ANOVA), simple linear regression and multiple linear regression analysis were conducted. Independent $\mathrm{t}$-test and ANOVA (Table 2) were performed to analyse each categorical risk factor that influenced the mean serum $25(\mathrm{OH}) \mathrm{D}$ level. Simple linear regression analysis (Table 3 ) was performed to determine the association of the factors with serum $25(\mathrm{OH}) \mathrm{D}$ level, whereas multiple linear regression analysis (Table 4) was performed to determine the factors associated with serum $25(\mathrm{OH}) \mathrm{D}$ level after being adjusted for the other confounders. $R^{2}$ values were reported to compare the variation explained by each multivariate model. The significant level was preset at 0.05 .

\section{Results}

A total of 858 teachers from 30 schools in all four districts (Pudu, Bangsar, Keramat and Sentul) from Kuala Lumpur participated in this study. The response rate of 
teachers was $41 \%$. Table 1 shows the baseline characteristics of the participants. The majority of them were females (90.9\%), married (84\%) and within the age range of 30-49 years (66.5\%). Most of them were Malays (74.2 \%), followed by Chinese (16.4\%), Indians (8.3\%) and others $(0.4 \%)$.

The weighted means for serum $25(\mathrm{OH}) \mathrm{D}$ and $\mathrm{PTH}$ were $17.97 \pm 7.32 \mathrm{ng} / \mathrm{ml}$ and $6.13 \pm 3.74 \mathrm{pmol} / \mathrm{L}$ respectively. A total of 578 participants $(67.4 \%)$ had vitamin $\mathrm{D}$ deficiency $(<20 \mathrm{ng} / \mathrm{ml})$. Indian participants

Table 1 Socio-demographic characteristics $(N=858)$ of participants

\begin{tabular}{|c|c|}
\hline Characteristic & $N$ (Weighted \%) \\
\hline \multicolumn{2}{|l|}{ Districts } \\
\hline Bangsar & $236(28.2)$ \\
\hline Keramat & $255(21.1)$ \\
\hline Pudu & $253(24.8)$ \\
\hline Sentul & $114(25.9)$ \\
\hline \multicolumn{2}{|l|}{ Gender } \\
\hline Male & $77(9.1)$ \\
\hline Female & $781(90.9)$ \\
\hline \multicolumn{2}{|l|}{ Age (years) } \\
\hline$<30$ & $137(15.9)$ \\
\hline 30-39 & $279(31.6)$ \\
\hline $40-49$ & $293(34.9)$ \\
\hline$\geq 50$ & $149(17.6)$ \\
\hline \multicolumn{2}{|l|}{ Ethnicity } \\
\hline Malay & $660(76.9)$ \\
\hline Chinese & $125(16.4)$ \\
\hline Indian & $63(8.3)$ \\
\hline Others & $10(0.4)$ \\
\hline \multicolumn{2}{|l|}{ Religion } \\
\hline Islam & $666(75.3)$ \\
\hline Buddhist & 99 (12.8) \\
\hline Hindu & $53(6.8)$ \\
\hline Christian & $34(4.5)$ \\
\hline Others & $6(0.5)$ \\
\hline \multicolumn{2}{|l|}{ Marital status ${ }^{b}$} \\
\hline Single & $103(14.6)$ \\
\hline Married & $611(84.0)$ \\
\hline Divorced/Widowed & $14(1.4)$ \\
\hline \multicolumn{2}{|l|}{ Body mass index $\left(\mathrm{kg} / \mathrm{m}^{2}\right)^{a}$} \\
\hline Underweight (<17.5) & $32(4.1)$ \\
\hline Normal (17.5-22.9) & $316(36.4)$ \\
\hline Overweight (23.0-27.9) & $207(24.2)$ \\
\hline Obese $(\geq 28.0)$ & $303(35.3)$ \\
\hline
\end{tabular}

${ }^{a}$ Classification according to World Health Organization for Asians ${ }^{\mathrm{b}} \mathrm{N}=728$
(80.9 \%) had the highest proportion of vitamin D deficiency, followed by Malays (75.6 \%), others (44.9\%) and Chinese $(25.1 \%)$. Among those with vitamin D deficiency, more than half of them were obese (39\%) and overweight (24\%) (data not shown). Females had a significantly lower weighted mean serum $25(\mathrm{OH}) \mathrm{D}$ level compared to males (Table 2). Weighted means of serum 25(OH)D level were lowest among the participants of Indian ethnicity, aged $<30$ years, obese $\left(\geq 28.0 \mathrm{~kg} / \mathrm{m}^{2}\right)$ and with higher body fat percentages (Tertile 3).

The weighted means of fat percentage and BMI were $28.1 \pm 8.0 \%$ and $25.66 \pm 5.06 \mathrm{~kg} / \mathrm{m}^{2}$ respectively. A total of 303 participants $(35.3 \%)$ were obese $\left(\geq 28.0 \mathrm{~kg} / \mathrm{m}^{2}\right)$, while $207(24.2 \%)$ were overweight.

Table 2 Weighted mean serum 25(OH)D level of sociodemographic characteristics and adiposity indicators

\begin{tabular}{|c|c|c|}
\hline \multirow[t]{2}{*}{ Characteristics } & Serum 25(OH)D & \multirow[t]{2}{*}{$p$-value } \\
\hline & Weighted mean, $\bar{x}(95 \% \mathrm{Cl})$ & \\
\hline \multicolumn{3}{|l|}{ Age (years) } \\
\hline$<30$ & 16.76 (15.56 to 17.97$)$ & \multirow[t]{4}{*}{0.001} \\
\hline $30-39$ & 17.24 (16.36 to 18.11$)$ & \\
\hline $40-49$ & 17.81 (16.86 to 18.78$)$ & \\
\hline$\geq 50$ & 20.69 (19.11 to 22.27) & \\
\hline \multicolumn{3}{|l|}{ Gender } \\
\hline Male & 25.27 (23.41 to 27.14 ) & \multirow[t]{2}{*}{$<0.001$} \\
\hline Female & 17.24 (16.68 to 17.80$)$ & \\
\hline \multicolumn{3}{|l|}{ Ethnicity } \\
\hline Malay & 16.57 (16.06 to 17.09) & \multirow[t]{4}{*}{$<0.001$} \\
\hline Chinese & 25.44 (23.84 to 27.05$)$ & \\
\hline Indian & 15.47 (13.98 to 16.96) & \\
\hline Others & 19.55 (14.18 to 24.92) & \\
\hline \multicolumn{3}{|l|}{ BMI $\left(\mathrm{kg} / \mathrm{m}^{2}\right)$} \\
\hline Underweight (<17.5) & 17.29 (14.15 to 20.43$)$ & \multirow[t]{4}{*}{$<0.001$} \\
\hline Normal (17.5-22.9) & 19.20 (18.23 to 20.17$)$ & \\
\hline Overweight (23.0-27.9) & 18.30 (17.02 to 19.57$)$ & \\
\hline Obese $(\geq 28.0)$ & 16.56 (15.82 to 17.30$)$ & \\
\hline \multicolumn{3}{|l|}{ Tertile BF \% } \\
\hline Tertile $1(\leq 24.77)$ & 18.92 (17.58 to 20.27) & \multirow[t]{3}{*}{0.037} \\
\hline Tertile 2 (24.78-31.62) & 16.93 (15.83 to 18.02$)$ & \\
\hline Tertile 3 ( $\geq 31.63)$ & 16.90 (15.92 to 17.88$)$ & \\
\hline \multicolumn{3}{|l|}{ Waist circumferences (cm) } \\
\hline \multicolumn{3}{|l|}{ Male } \\
\hline$<90 \mathrm{~cm}$ & 26.06 (23.54 to 28.57) & \multirow[t]{2}{*}{0.227} \\
\hline$\geq 90 \mathrm{~cm}$ & 23.83 (21.20 to 26.46$)$ & \\
\hline \multicolumn{3}{|l|}{ Female } \\
\hline$<80 \mathrm{~cm}$ & 17.80 (17.01 to 18.59$)$ & \multirow[t]{2}{*}{0.023} \\
\hline$\geq 80 \mathrm{~cm}$ & 16.51 (15.74 to 17.29$)$ & \\
\hline
\end{tabular}


Among those who were obese, 222 (74.4 \%) had vitamin $\mathrm{D}$ deficiency. In the univariate analysis, BMI $(\beta=$ $-0.23, p<0.001)$ and fat percentage $(\beta=-0.14, p<$ $0.005)$ were negatively associated with serum $25(\mathrm{OH}) \mathrm{D}$ level, but not waist circumference $(p>0.05)$. The level of PTH and the sun avoidance score were also negatively associated with serum $25(\mathrm{OH}) \mathrm{D}$ level $(p<0.001)$, while age $(p<0.001)$ and systolic blood pressure $(p<0.05)$ showed positive association with serum 25(OH)D level (Table 3).

Table 4 shows the multiple linear regression analysis of all the risk factors affecting serum 25(OH)D level. Model 1 (Reference) comprised of all the significant factors in the univariate analysis (except PTH) without being adjusted for adiposity indicators, while Models 2, 3 and 4 comprised of Model $1+$ BMI, Model $1+$ waist circumference and Model $1+$ body fat percentage respectively. PTH was excluded in the analysis as it was an outcome of serum 25(OH)D level. By comparing all models that were adjusted for various adiposity indicators, there was not much difference in $R^{2}$ between each of the adiposity indicators (BMI, waist circumference and body fat percentage). There was comparable $R^{2}$ value in the models with BMI or waist circumference $\left(R^{2}=33.0 \%\right)$ and it was slightly lower in the model with fat percentage $\left(R^{2}=32.3 \%\right)$.

Among all the adiposity indicators, only BMI and waist circumference $(p<0.05)$ were significantly associated with serum $25(\mathrm{OH}) \mathrm{D}$ level after adjusted for all the

Table 3 Risk factors of serum 25(OH)D level among the participants

\begin{tabular}{lll}
\hline & Serum 25(OH)D & $p$-value \\
& Unstandardized $B \pm$ SE & \\
\hline Age & $0.13 \pm 0.03$ & $<0.001$ \\
Gender & $-3.91 \pm 0.38$ & $<0.001$ \\
Ethnicity & & \\
$\quad$ Chinese & Reference & \\
$\quad$ Malay & $-8.87 \pm 0.86$ & $<0.001$ \\
$\quad$ Indian & $-9.98 \pm 1.12$ & $<0.001$ \\
$\quad-5.90 \pm 2.85$ & 0.039 \\
Others & $-0.23 \pm 0.05$ & $<0.001$ \\
Body mass index (BMI) (kg/m²) & $-0.14 \pm 0.04$ & 0.002 \\
Waist circumference (cm) & $-0.32 \pm 0.02$ & 0.152 \\
PTH (pmol/L) & $-0.44 \pm 0.09$ & $<0.001$ \\
Physical activity (METs/min) & $1.17 \pm 0.33$ & 0.929 \\
Sun avoidance score & $-1.03 \pm 0.27$ & $<0.001$ \\
Sun exposure score & $0.03 \pm 0.53$ & 0.955 \\
Systolic blood pressure & $0.03 \pm 0.02$ & 0.029 \\
Diastolic blood pressure & $0.02 \pm 0.02$ & 0.334 \\
\hline Gender Mas & &
\end{tabular}

Gender: Males $=1$, Females $=2$
Table 4 Different adiposity indicators affecting serum 25(OH)D level after being adjusted for age, gender, ethnicity, sun avoidance score and systolic blood pressure ${ }^{a}$

\begin{tabular}{|c|c|c|c|c|}
\hline & \multicolumn{4}{|c|}{ Unstandardized $B$} \\
\hline & Model 1 & Model 2 & Model 3 & Model 4 \\
\hline Age & 0.022 & 0.033 & 0.030 & 0.005 \\
\hline Gender & $-7.485^{* *}$ & $-7.461^{* *}$ & $-7.918^{* *}$ & $-7.426^{* *}$ \\
\hline \multicolumn{5}{|l|}{ Ethnicity } \\
\hline Chinese & Reference & Reference & Reference & Reference \\
\hline Malays & $-9.030^{* *}$ & $-8.512^{* *}$ & $-8.763^{* *}$ & $-9.046^{* *}$ \\
\hline Indians & $-9.550 * *$ & $-9.070^{* *}$ & $-9.138^{* *}$ & $-9.241^{* *}$ \\
\hline Others & -5.473 & -4.965 & -5.289 & -2.845 \\
\hline Sun avoidance score & -0.047 & -0.081 & -0.055 & 0.413 \\
\hline Systolic blood pressure & 0.001 & 0.013 & 0.011 & 0.011 \\
\hline BMI & & $-0.140^{*}$ & & \\
\hline Waist circumference & & & $-0.052^{*}$ & \\
\hline Fat percentage (\%) & & & & -0.016 \\
\hline$R^{2}$ & $32.0 \%$ & $32.8 \%$ & $32.6 \%$ & $32.3 \%$ \\
\hline
\end{tabular}

${ }^{a}$ PTH was excluded in the analysis as it is an outcome of serum $25(\mathrm{OH}) \mathrm{D}$ level ${ }^{* *} p<0.001,{ }^{*} p<0.05$

Gender: Males $=1$, Females $=2$

Model $1=$ Controlled for age, gender, ethnicity, sun avoidance score, systolic blood pressure

Model $2=$ Model $1+$ BMI

Model $3=$ Model $1+$ Waist Circumference

Model $4=$ Model $1+$ Fat Percentage (\%)

confounders. The other factors significantly associated with serum $25(\mathrm{OH}) \mathrm{D}$ level were Malays, Indians and females $(p<0.001)$.

Our results demonstrated that adiposity was not the main risk factor that affected serum 25(OH)D level. The difference in $R^{2}$ between the reference model and the model adjusted for adiposity indicators (BMI and waist circumference) was only approximately $1.0 \%$. Table 5 shows that the more influential factors affecting serum $25(\mathrm{OH}) \mathrm{D}$ level were ethnicity and gender, as the difference in the $R^{2}$ values were $16.9 \%$ and $7.1 \%$ respectively.

\section{Discussion}

Based on the report from the Ministry of Science Technology and Innovation (MOSTI) in 2011, Malaysians received at least six hours of sunshine daily. However, many studies showed a high prevalence of vitamin D deficiency among the Malaysian population. Similarly, we found a high proportion of our participants had vitamin D deficiency $(<20 \mathrm{ng} / \mathrm{ml})$. Females had lower levels of vitamin D compared to males, similar as the previous findings [5, 28]. This could largely be explained by their clothing styles such as wearing veils, long sleeves, long skirts, using umbrellas and sunblock lotion. Our findings showed that there was a negative association between serum 
Table 5 Contributions of gender and ethnicity to $R^{2}$ for serum 25(OH)D level

\begin{tabular}{|c|c|c|c|}
\hline & \multicolumn{3}{|l|}{ Unstandardized $B$} \\
\hline & Model 1 (Reference Model) & Model 2 & Model 3 \\
\hline Age & 0.033 & 0.022 & $0.138^{* *}$ \\
\hline Sun avoidance score & -0.081 & $-0.638^{*}$ & -0.377 \\
\hline Systolic blood pressure & 0.013 & 0.025 & 0.021 \\
\hline BMI & $-0.140^{*}$ & $-0.145^{*}$ & $-0.327^{* *}$ \\
\hline \multicolumn{4}{|l|}{ Ethnicity } \\
\hline Chinese & Reference & Reference & \\
\hline Malays & $-8.512^{* *}$ & $-8.317^{* *}$ & \\
\hline Indians & $-9.070^{* *}$ & $-9.558^{* *}$ & \\
\hline Others & -4.965 & $-5.913^{*}$ & \\
\hline Gender & $-7.461^{* *}$ & & $-7.269^{* *}$ \\
\hline$R^{2}$ & $32.8 \%$ & $25.7 \%$ & $15.9 \%$ \\
\hline \multicolumn{2}{|l|}{ Difference in $R^{2}$} & $7.1 \%$ & $16.9 \%$ \\
\hline \multicolumn{4}{|c|}{$\begin{array}{l}\text { ** } p<0.001,{ }^{*} p<0.05 \\
\text { Gender: Males }=1 \text {, Females }=2 \\
\text { Model } 1=\text { Predictors: age, sun avoidance score, systolic blood pressure, BMl, ethnicity, gender } \\
\text { Model } 2=\text { Model } 1 \text { - Gender } \\
\text { Model } 3=\text { Model } 1 \text { - Ethnicity } \\
\text { Difference in } R^{2}=R^{2} \text { in Model } 1 \text { (Reference Model) }-R^{2} \text { in Model 2/Model } 3\end{array}$} \\
\hline
\end{tabular}

$25(\mathrm{OH}) \mathrm{D}$ level and sun avoidance score $(p<0.001)$ in the univariate analysis. However, only gender remained significant in the multivariate analysis. Cultural perception among Asians, especially the females' preference for fairer skin $[29,30]$ may influence them to avoid the sun, have clothing styles that covered most parts of their bodies or use sun block lotion when going outdoor.

Similar with the study by Nurbazlin's et al. [20], higher proportions of Indian and Malay women from our study had vitamin $\mathrm{D}$ deficiency compared to Chinese. This could be due to the darker skin color of Indians (Fitzpatrick skin type VI) and Malays (types V and VI) compared to Chinese (types III and IV) [31]. Higher melanin content in dark skin inhibits vitamin D synthesis [16]. Tsiaras et al. reported that those with darker skin pigmentation or higher melanin content required longer sun exposure compared to those with lighter skin to produce the same amount of vitamin $\mathrm{D}$ level needed in the body [32]. Ethnicity was significant in both univariate and multivariate analyses.

Lower vitamin D level was more prevalent with advancing age $[33,34]$. Aging decreases the skin's capacity to produce vitamin $\mathrm{D}$ [35]. Among the elderly, there is a decreased hydroxylation of vitamin $\mathrm{D}$ and response towards the intestinal mucosa to circulate vitamin D [36]. However, there are also studies reported that serum $25(\mathrm{OH}) \mathrm{D}$ level did not decrease with age $[16,30]$. A study from Iran reported that $25(\mathrm{OH}) \mathrm{D}$ level remained constant from the age of 20 to 60 years among men [37]. Our results showed that older participants had higher serum 25(OH)D level compared with the younger participants. This could be due to younger individuals perceiving fair skin as a symbol of high social class and attractiveness [30]. As a result, they avoided being exposed to sunlight. In addition, our participants were in the age range of 30 to 60 years old, where they were relatively healthy compared to those who were older. Further studies should be carried out to explore the serum 25(OH)D level among adults over a wider spectrum of age.

Obesity is a well established risk factor for cardiovascular diseases [26, 38, 39], which increase morbidity and mortality in both developed and developing countries [25]. Similar with the previous findings [5, 40-43], obesity was significantly associated with serum $25(\mathrm{OH}) \mathrm{D}$ level. This may be explained by the characteristics of vitamin $\mathrm{D}$ itself as a fat soluble vitamin. Higher body fat reduces the availability of circulating $25(\mathrm{OH}) \mathrm{D}$ [16]. Obese individuals have higher fat content, which might block $25(\mathrm{OH}) \mathrm{D}$ from being sequestered into the body and eventually lowers the circulating serum 25(OH)D. We found BMI $(p<0.001)$ and body fat percentage $(p<0.05)$ to be negatively associated with serum 25(OH)D level in the univariate analysis. However, in the multivariate analysis, body fat percentage became insignificant, but higher BMI and larger waist circumference were significantly associated with lower serum 25(OH)D level $(p<0.05)$.

There were controversial results in the association of body fat percentage with serum $25(\mathrm{OH}) \mathrm{D}$ level. Arunabh et al. found that serum 25(OH)D level were more strongly associated with body fat percentage compared 
to BMI, indicating that it was adiposity, not simply body mass that influenced the serum 25(OH)D level [44]. However, we found contradicting results, as similarly reported by Nurbazlin et al. and Chin et al. [20, 21]. This could be due to the foot-to-foot BIA machine that may not be as accurate as the direct segmental multifrequency (DSM)-BIA. In addition, our participants might not adhere to certain conditions to be followed such as fasting, avoid eating or drinking, or avoid exercising before measurements.

The present study found an inverse association between waist circumference and 25(OH)D level after adjusted for all confounders, as similarly reported by Lu's et al. [45]. Central obesity has been linked with the increase in cardiovascular risks, development in hyperinsulinemia, insulin resistance, heart disease and high blood pressure [46] that might affect serum $25(\mathrm{OH}) \mathrm{D}$ level. Therefore, it is important to measure both the overall and central obesity while accessing vitamin $\mathrm{D}$ status and its cardiovascular risks in the future.

Parathyroid Hormone (PTH) is a hormone maintaining normal serum concentrations of calcium and phosphate. It is regulated through the levels of serum vitamin $\mathrm{D}$ and calcium [47]. Vitamin D deficiency is generally associated with an increase in PTH [48-50], as similarly found in our results. An elevated PTH concentration is known to be associated with cardiometabolic diseases [51, 52]. Therefore, there is a need to monitor both levels of serum $25(\mathrm{OH}) \mathrm{D}$ and PTH. On the other hand, some studies showed no significant association between 25(OH)D level and PTH $[7,17,20,30]$. Serum calcium may be another factor that influences the level of PTH. Further investigation should be carried out on this aspect.

We did not find physical activity to be associated with serum 25(OH)D level. However, there were studies that reported significant association between physical activity with vitamin $D$ level $[16,53]$. Individuals who exercised may be exposed to more sunlight which contributed to the synthesis of vitamin D [54]. However, it remained unclear whether doing physical activity or exercise itself contributed to the elevated serum 25(OH)D level [53], or due to sun exposure from the exercise.

Among the significant factors associated with serum 25(OH)D level such as ethnicity, gender and BMI, we found that the contribution of BMI to the $R^{2}$ was only $0.8 \%$. The two most influential factors affecting serum $25(\mathrm{OH}) \mathrm{D}$ level were ethnicity and gender. Ethnicity as the proxy of skin pigmentation and gender based behaviours were more dominant in contributing to serum 25(OH)D level. Health education should be targeted in these gender based behaviours, as skin pigmentation is non-modifiable.
There are some limitations that warrant some discussion. First, there are various methods of determining serum $25(\mathrm{OH}) \mathrm{D}$ which may influence the readings of $25(\mathrm{OH}) \mathrm{D}$ level. Some of the immunoassays underestimate 25-hydroxyvitamin $\mathrm{D}$ metabolites due to the differences in the affinity between the antibodies or D-binding protein employed. Secondly, no gathered information on the medications and vitamin D supplements used among participants was another limitation. Recall bias from participants may also influence our results.

Notwithstanding the above limitations, the present study had several strengths. We tested the associations of multiple adiposity indicators with serum $25(\mathrm{OH}) \mathrm{D}$ level. Our sample comprised of multi-ethnic adults, thus making it possible to infer to all adults in Kuala Lumpur. We also established gender based behaviours as one of the important factors influencing serum 25(OH)D level. Health education and promotion programs should be targeted among the females who are at high risk of vitamin D deficiency. Efforts should be targeted in the methods to acquire more vitamin D. Further studies are required to ascertain if higher vitamin $\mathrm{D}$ is required for this population.

\section{Conclusions}

Our participants had a high prevalence of vitamin D deficiency. In the multivariate analysis, Malays, Indians, females, higher Body Mass Index (BMI) and larger waist circumference were significantly associated with lower serum 25(OH)D level. Skin pigmentation and gender based behaviours were more dominant in contributing to serum $25(\mathrm{OH}) \mathrm{D}$ level. Health programs should be carried out to educate the community on how to prevent vitamin D deficiency in the future.

\section{Competing interests \\ The authors declare that they have no competing interests.}

\section{Authors' contributions}

FMM designed the study. ISS and FMM conducted the study. Both authors performed the statistical analysis and drafted the manuscript. Both authors read and approved the final manuscript.

\section{Authors' information}

ISS is a post-graduate candidate pursuing her Master in Medical Science (Research). FMM is an academic staff of the university and supervises the work of ISS. FMM is the principal investigator of CLUSTer study which contributes the data for this manuscript.

\section{Acknowledgements}

We would like to express our sincere appreciation to the Ministry of Education, Malaysia, all teachers and staff from all selected secondary schools in Kuala Lumpur that participated in this study. Sincere appreciation also given to all CLUSTer team members involved in this research. Our project was supported by the HIR-MOHE Grant (H-20001-00-E00069) and the University of Malaya Research Grant (RG 466-12HTM).

Received: 30 December 2014 Accepted: 2 March 2016 Published online: 07 March 2016 


\section{References}

1. Pittas AG, Dawson-Hughes B, Li T, Van Dam RM, Willett WC, Manson JE, Hu FB. Vitamin $D$ and calcium intake in relation to type 2 diabetes in women. Diabetes Care. 2006;29(3):650-6.

2. Rosen CJ, Adams JS, Bikle DD, Black DM, Demay MB, Manson JE, Murad MH, Kovacs CS. The nonskeletal effects of vitamin D: an Endocrine Society scientific statement. Endocr Rev. 2012;33(3):456-92.

3. Gorham ED, Garland CF, Garland FC, Grant WB, Mohr SB, Lipkin M, Newmark HL, Giovannucci E, Wei M, Holick MF. Optimal vitamin D status for colorectal cancer prevention: a quantitative meta analysis. Am J Prev Med. 2007;32(3):210-6.

4. Holick MF. The vitamin D epidemic and its health consequences. J Nutr. 2005;135(11):2739-48.

5. Moy FM, Bulgiba A. High prevalence of vitamin D insufficiency and its association with obesity and metabolic syndrome among Malay adults in Kuala Lumpur, Malaysia. BMC Public Health. 2011:11(1):735.

6. L-O C, Aekplakorn W, Ongphiphadhanakul B. Regional variation and determinants of vitamin D status in sunshine-abundant Thailand. BMC Public Health. 2011;11(1):853.

7. Elsammak MY, Al-Wossaibi AA, Al-Howeish A, Alsaeed J. High prevalence of vitamin D deficiency in the sunny Eastern region of Saudi Arabia: a hospitalbased study. East Mediterr Health J. 2011;17(4):317-22.

8. Hashemipour S, Larijani B, Adibi H, Javadi E, Sedaghat M, Pajouhi M, Soltani A, Shafaei AR, Hamidi Z, Fard AR. Vitamin D deficiency and causative factors in the population of Tehran. BMC Public Health. 2004;4(1):38.

9. Holick MF, Chen TC. Vitamin D deficiency: a worldwide problem with health consequences. Am J Clin Nutr. 2008;87(4):1080S-6S.

10. Jones G. Pharmacokinetics of vitamin D toxicity. Am J Clin Nutr. 2008;88:582-6.

11. Cranney C, Horsely T, O'Donnell S, Weiler H, Ooi D, Atkison S. Effectiveness and safety of vitamin D. In: Assessment No 158 prepared by the University of Ottawa Evidence-based Practice Center under Contract No 290-020021. 2007.

12. Holick MF. Vitamin D deficiency. N Engl J Med. 2007;357(3):266-81.

13. NHMS. National Health Morbidity Survey. Ministry of Health Malaysia: Putrajaya; 2011.

14. Wortsman J, Matsuoka LY, Chen TC, Lu Z, Holick MF. Decreased bioavailability of vitamin D in obesity. Am J Clin Nutr. 2000;72(3):690-3.

15. Foss Y. Vitamin D deficiency is the cause of common obesity. Med Hypotheses. 2009;72(3):314-21.

16. Rahman SA, Chee WSS, Yassin Z, Chan SP. Vitamin D status among postmenopausal Malaysian women. Asia Pac J Clin Nutr. 2004;13(3):255-60.

17. Green TJ, Skeaff CM, Rockell JEP, Venn BJ, Lambert A, Todd J, Khor GL, Loh SP, Muslimatun S, Agustina R. Vitamin D status and its association with parathyroid hormone concentrations in women of child-bearing age living in Jakarta and Kuala Lumpur. Eur J Clin Nutr. 2008;62(3):373-8.

18. Moy FM. Vitamin D status and its associated factors of free living Malay adults in a tropical country, Malaysia. J Photochem Photobiol B Biol. 2011;104(3):444-8.

19. Ari I, Suriah AR, Zalifah MK, Winnie CSS, Zaitun Y, Asmaa', Parid M. Effect of nutrition education and sun exposure on vitamin D status among postmenopausal Malay women. Int J Sci Eng Investig. 2012;1(10):91-7.

20. Nurbazlin M, Chee WSS, Rokiah P, Tan ATB, Chew YY, Siti Nusaibah AR, Chan SP. Effects of sun exposure on $25(\mathrm{OH})$ vitamin D concentration in urban and rural women in Malaysia. Asia Pac J Clin Nutr. 2013;22(3):391.

21. Chin K-Y, Ima-Nirwana S, Ibrahim S, Mohamed IN, Wan Ngah WZ. Vitamin D status in Malaysian men and its associated factors. Nutrients. 2014;6(12):5419-33.

22. Moy FM, Hoe VC, Hairi NN, Buckley B, Wark PA, Koh D, Bulgiba AM. Cohort study on clustering of lifestyle risk factors and understanding its association with stress on health and wellbeing among school teachers in Malaysia (CLUSTer)-a study protocol. BMC Public Health. 2014;14(1):611

23. Holick MF, Binkley NC, Bischoff-Ferrari HA, Gordon CM, Hanley DA, Heaney $\mathrm{RP}$, Murad MH, Weaver CM. Evaluation, treatment, and prevention of vitamin D deficiency: an Endocrine Society clinical practice guideline. J Clin Endocrinol Metab. 2011;96(7):1911-30

24. Naveh-Many T, Silver J. Vitamin D and the parathyroid. In: Feldman D, Glorieux F, Wesley Pike J, editors. Vitamin D. 2nd ed. London: Elsevier; 2004

25. World Health Organization. Obesity: Preventing and Managing The Global Epidemic. In: WHO Technical Report Series 894. Geneva: WHO; 2000

26. National Institute of Health, Lung and Blood Institute. Clinical guidelines on the identification, evaluation and treatment of overweight and obesity in adults, the evidence report. Obes Res. 1998;6:51-209.
27. Chu AH, Moy FM. Reliability and validity of the malay international physical activity questionnaire (IPAQ-M) among a Malay population in Malaysia. Asia Pac J Public Health. 2012. doi:10.1177/1010539512444120.

28. Chan SP, Chew YY, Vijay A, Lim SS, Tan ATB, Hazizi AS, Zaitun Y, Joseph A Manivasagar M, Rokiah P. Vitamin D inadequacy in Malaysia: preliminary analysis of a rural vs urban population. 2009

29. Li EP, Min HJ, Belk RW, Kimura J, Bahl S. Skin lightening and beauty in four Asian cultures. Adv Consum Res. 2008:35:444-9.

30. Ho-Pham LT, Nguyen ND, Lai TQ, Eisman JA, Nguyen TV. Vitamin D status and parathyroid hormone in a urban population in Vietnam. Osteoporos Int. 2011;22(1):241-8.

31. Sng J, Koh D, Siong WC, Choo TB. Skin cancer trends among Asians living in Singapore from 1968 to 2006. J Am Acad Dermatol. 2009;61(3):426-32.

32. Tsiaras WG, Weinstock MA. Factors influencing vitamin D status. Acta Derm Venereol. 2011:91(2):115-24.

33. Jacques PF, Felson DT, Tucker KL, Mahnken B, Wilson PW, Rosenberg $\mathbb{H}_{\text {, }}$ Rush D. Plasma 25-hydroxyvitamin D and its determinants in an elderly population sample. Am J Clin Nutr. 1997;66:929-36.

34. Dubbelman R, Jonxis JH, Muslkiet FA, Saleh AE. Age-dependent vitamin D status and vertebral condition of white women living in Curacao. Am J Clin Nutr. 1993:58:106-9.

35. MacLaughlin J, Holick MF. Aging decreases the capacity of human skin to produce vitamin D3. J Clin Invest. 1985;76(4):1536-8.

36. Heaney RP. Lessons for nutritional science from vitamin D. Am J Clin Nutr. 1999;69:825-6.

37. Masoompour SM, Sadegholvaad A, Larijani B, Ranjbar-Omrani G. Effects of age and renal function on vitamin D status in men. Arch Iran Med. 2008:11:377-81.

38. Rimm EB, Stampfer MJ, Giovannucci E, Ascherio A, Spiegelman D, Colditz GA, Willet WC. Body size and fat distribution as a predictors of coronary heart disease among middle-aged and older US men. Am J Epidemiol. 1995:141:1117-27.

39. World Health Organization. Preventing Chronic Disease- A Vital Investment. In: WHO and The Public Health Agency of Canada. Geneva: WHO; 2005.

40. Liu S, Song Y, Ford ES, Manson JE, Buring JE, Ridker PM. Dietary calcium, vitamin $\mathrm{D}$, and the prevalence of metabolic syndrome in middle-aged and older US women. Diabetes Care. 2005;28(12):2926-32.

41. McCarty MF. Poor vitamin D status may contribute to high risk for insulin resistance, obesity, and cardiovascular disease in Asian Indians. Med Hypotheses. 2009;72(6):647-51.

42. McGill AT, Stewart JM, Lithander FE, Strik CM, Poppitt SD. Relationships of low serum vitamin D3 with anthropometry and markers of the metabolic syndrome and diabetes in overweight and obesity. Nutr J. 2008;7(1):4.

43. Rueda S, Fernández-Fernández C, Romero F, De Osaba MJM, Vidal J. Vitamin D, PTH, and the metabolic syndrome in severely obese subjects. Obes Surg. 2008;18(2):151-4.

44. Arunabh S, Pollack S, Yeh J, Aloia JF. Body fat content and 25hydroxyvitamin D levels in healthy women. J Clin Endocrinol Metab. 2003:88(1):157-61.

45. Lu L, Yu Z, Pan A, Hu FB, Franco OH, Li H, Li X, Yang X, Chen Y, Lin X. Plasma 25-hydroxyvitamin D concentration and metabolic syndrome among middle-aged and elderly Chinese individuals. Diabetes Care. 2009; 32(7):1278-83.

46. Sowers JR. Obesity as a cardiovascular risk factor. Am J Med. 2003:115(8):37-41.

47. Steingrimsdottir L, Gunnarsson O, Indridason OS, Franzson L, Sigurdsson G. Relationship between serum parathyroid hormone levels, vitamin D sufficiency, and calcium intake. JAMA. 2005;294(18):2336-41.

48. Souberbielle JC, Cormier C, Kindermans C, Gao P, Cantor T, Forette F, Baulieu EE. Vitamin D Status and Redefining Serum Parathyroid Hormone Reference Range in the Elderly 1. J Clin Endocrinol Metab. 2001:86(7):3086-90.

49. Yan L, Prentice A, Zhang H, Wang X, Stirling DM, Golden MM. Vitamin D status and parathyroid hormone concentrations in Chinese women and men from north-east of the People's Republic of China. Eur J Clin Nutr. 2000:54(1):68-72

50. Nakamura K, Nashimoto M, Matsuyama S, Yamamoto M. Low serum concentrations of 25-hydroxyvitamin D in young adult Japanese women: a cross sectional study. Nutrition. 2001;17(11):921-5.

51. Lavie CI, DiNicolantonio Jل Jilani RV O'Keefe JH. Vitamin D and cardiovascular health. Circulation. 2013;128(22):2404-6. 
52. Zittermann A. Vitamin D and disease prevention with special reference to cardiovascular disease. Prog Biophys Mol Biol. 2006;92(1):39-48.

53. Brock K, Huang WY, Fraser DR, Ke L, Tseng M, Stolzenberg-Solomon R, Peters U, Ahn J, Purdue M, Mason RS. Low vitamin D status is associated with physical inactivity, obesity and low vitamin D intake in a large US sample of healthy middle-aged men and women. J Steroid Biochem Mol Biol. 2010;121(1):462-6.

54. Houston DK, Cesari M, Ferrucci L, Cherubini A, Maggio D, Bartali B, Johnson MA, Schwartz GG, Kritchevsky SB. Association between vitamin D status and physical performance: the InCHIANTI study. J Gerontol Ser A Biol Med Sci. 2007:62(4):440-6.

Submit your next manuscript to BioMed Central and we will help you at every step:

- We accept pre-submission inquiries

- Our selector tool helps you to find the most relevant journal

- We provide round the clock customer support

- Convenient online submission

- Thorough peer review

- Inclusion in PubMed and all major indexing services

- Maximum visibility for your research

Submit your manuscript at www.biomedcentral.com/submit
Biomed Central 